\title{
Name in the Kohau Rongorongo script (Easter Island)
}

\section{Albert DAVLETSHIN}

\section{(2) OpenEdition \\ 1 Journals}

\section{Electronic version}

URL: http://journals.openedition.org/jso/6658

DOI: $10.4000 /$ jso.6658

ISSN: $1760-7256$

\section{Publisher}

Société des océanistes

\section{Printed version}

Date of publication: 30 June 2012

Number of pages: 95-110

ISBN: 978-2-85430-032-1

ISSN: 0300-953x

\section{Electronic reference}

Albert DAVLETSHIN, « Name in the Kohau Rongorongo script (Easter Island) », Journal de la Société des Océanistes [Online], 134 | 1er semestre 2012, Online since 12 July 2012, connection on 22 April 2019. URL : http://journals.openedition.org/jso/6658 ; DOI : 10.4000/jso.6658 


\title{
Name in the Kohau Rongorongo script (Easter Island)
}

by

\author{
Albert DAVLETSHIN*
}

\begin{abstract}
Many interpretations of the undeciphered Kohau Rongorongo script of Easter Island have been proposed, but nowadays only the suggestion about a genealogy on the Small Santiago Tablet offered by Yuri Knorosov and Nikolai Butinov in 1956 seems to be trusted. The paper seeks answers on two controversial questions related to this suggestion: What is the function of sign 076? And why the a possessive marker is absent there? Three Kohau Rongorongo texts represent name lists, supposedly, of either defeated and sacrificed enemies or newborns. Structural analysis of the tablets shows that some signs, which frequently appear in a certain position in the names, may be titles. Many names are complemented with possible titles, others are not. The genealogy consists of six names marked by the same title, which follow a passage free of names. Probably, this passage is inserted into the name list and refers to the most prominent person mentioned. The proposed suggestions indicate that Kohau Rongorongo texts served as an important media of sociopolitical integration.
\end{abstract}

KEYWORDS: Kohau Rongorongo Script, Easter Island, logo-syllabic writing systems, structural analysis, artificial bilinguals, title, rank, pre-Contact Polynesia

Natives of Easter Island were inventors of a unique writing system called Kohau Rongorongo. As far as we know, no other Polynesian peoples at the time of their discovery possessed an indigenous writing system. The Kohau Rongorongo script remains undeciphered (see for example, Barthel, 1993; Vignes, 1990). I shall avoid here a lengthy repetition of the discovery of the Kohau

\section{RÉSUMÉ}

Si plusieurs interprétations de l'écriture encore indéchiffrée de l'île de Pâques (Kohau Rongorongo) ont été proposées, aujourd'hui seule la suggestion faite par Yuri Knorosov et Nikolai Butinov, que la petite tablette de Santiago contient une généalogie, semble acceptée. L'article tente de répondre à deux questions controversées liées à cette suggestion: quelle est la fonction du signe 076 ? Et pourquoi le possessif a est-il absent? Trois textes en Kohau Rongorongo sont des listes de noms, que l'on suppose être des noms soit d'ennemis vaincus ou sacrifiés soit de nouveau-nés. L'analyse structurale des tablettes révèle que certains signes, qui apparaissent souvent à une place déterminée dans les noms, pourraient être des titres. De nombreux noms sont assortis de titres potentiels, d'autres ne le sont pas. La généalogie est composée de six noms marqués par le même titre et se réfère à la personne la plus éminente. Les suggestions proposées indiquent que les textes en Kohau Rongorongo servaient à l'intégration sociopolitique.

MotS-CLÉS: Écriture Kohau Rongorongo, île de Pâques, systèmes d'écriture logo-syllabiques, analyse structurale, textes bilingues, titre, rang, Polynésie d'avant contact

Rongorongo tablets and the history of the various attempts at decipherment - since such a subject calls for independent investigation. I can do no more than mention the most interesting and important, in my opinion, works (Jaussen, 1893; Harrison, 1874; Piotrowski, 1925; Métraux, 1940: 389-411; Kudrjavtsev, 1949; Imbelloni, 1951; Butinov and Knorosov, 1956;

* Knorosov Centre for Mesoamerican Studies, Russian State University for the Humanities, Moscow, aldavletshin@mail.ru 
Barthel, 1958; Kondratov, 1969: 169-192; Fischer, 1993). I shall also avoid arguing my view of the Kohau Rongorongo script as an exemplary logo-syllabic writing system ${ }^{1}$, texts of which are written without omitting any grammatical markers in a language that is a direct ancestor of Modern Rapanui. The reasons are the following: on one hand, it is serious and extensive topic, and, on the other, it is quite obvious from the script itself and ethnohistoric sources we have at our disposal. Nonetheless, some essential points should be presented:

- First, the rigorous and systematic structural analysis from the conservative viewpoint still is to be applied to the Kohau Rongorongo tablets, for the numerous interpretative efforts cannot be called successful (Harrison, 1874; Métraux, 1940: 400411; Butinov and Knorosov, 1956; Kondratov, 1969: 169-192; Fischer, 1995).

- Second, the identification of the language of the tablets never has been made on the basis of the inscriptions themselves (Butinov and Knorosov, 1956; Kondratov, 1969: 169-192).

- Third, in spite of some claims (Butinov and Knorosov, 1956; Kondratov, 1969: 169-192; Fedorova, 1982; Macri, 1996), the Kohau Rongorongo script has not received required attention as an example of the logo-syllabic writing system.

- Fourth, there are no bilingual texts in the strict sense of the word known.

A "consensus" exists among the scholars regarding the only interpretation, namely, the sequence of signs representing a genealogy as identified by Nikolai Butinov and Yuri Knorosov in 1956 (Barthel, 1958: 308, 1993; Macri, 1996; Guy, 1998a-b). Butinov and Knorosov's genealogy is the only artificial bilingual text securely identified until the date. By the term "artificial bilingual texts" I understand cases, when either a particular structure of a text or contexts of an inscription permit us to compare it with extant texts in a given language and at least partially recognise its content.

\section{Name pattern in the Kohau Rongorongo script according to Butinov and Knorosov 1956}

As has been originally noted by Nikolai Butinov and Yuri Knorosov (1956), there is a sequence consisting of six groups of signs on the Small Santiago Tablet, Verso, Lines 5-6 (fig. 1). The same sign "Man" appears at the beginning

\section{Gv6}

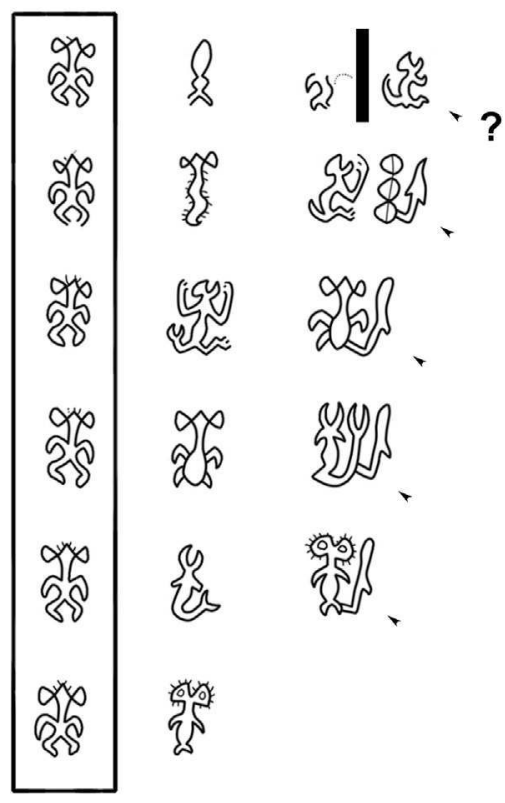

FIGURE 1. - Nikolai Butinov and Yuri Knorosov's genealogy and its surroundings on the Small Santiago Tablet, Verso. The sign "Man" (=TB200) is marked off by the frame and "Phallus" (=TB076) by arrows (after Paul Horley's drawings by his courtesy)

of each group. It is likely that this is a name list, and that the sign "Man" corresponds to the particle $k o$, which precedes personal names. The signs "Seating Man with Lifted Hand" and "Turtle" follow the sign "Man" in the third group as do the signs "Turtle" and "Shark" in the fourth group, the signs "Shark" and "Octopus" in the fifth group, and the only sign "Octopus" in the sixth one. Thus, the second sign of each group - that follows the sign "Man" stands for the first in the following group. This sort of alignment suggests that it is not just a list of names, but a genealogy ascending from a descendant to an ancestor. The second sign in the third, fourth and fifth groups would be the father's name. Names of Hotu Matu'a's descendants from the genealogy in the Gabriel Hereveri Manuscript (after Barthel, 1959: 79), for example, are composed in the same fashion:
Hotu Iti a Miru
Tuи a Hotu Iti
Honga a Tuu
Hotu Iti [son] of Miru
Te Kena a Honga
Tuu [son] of Hotu Iti
Tuukoihu a Te Kena
Honga [son] of Tuu
Te Kena [son] of Honga
Tuukoihu [son] of Te Kena

The pattern of the name in the Kohau Rongorongo texts was examined by Yuri Knorosov's

1. A logo-syllabic writing system is a writing comprised of word-signs or logograms and phonetic signs or syllabograms. The logogram is a sign, which spells a word and denotes its meaning. The phonetic sign is a sign, which spells a syllable, but has no meaning (see for example, Gelb, 1963: 250, 253). 
followers. The last sign in each group depicts "phallus". According to Metoro Tauara, the sign should be read as URE ure "penis, semen, clan". As Alexander Kondratov has stated (1969: 169-192), in all likelihood the sign in question is a patronymic marker, something similar to the Russian - вич "patronymic suffix". The facts that "Phallus" is of very frequent use in the texts and that it shows a peculiar distribution is in favour of this hypothesis (see below). Irina Fedorova (1982: 56-60) has noted that the sign "Phallus" is not identical in its position with the article of personal name $a$ in Modern Rapanui, which marks the boundary between the personal name in strict sense and the father's name in the name of son. Irina Fedorova suggests that the $a$ article replaced ure, which was originally used as the father name's marker ${ }^{2}$. Having pointed out that the sign appears in final position in a large series of groups (more than 100) on the Santiago Staff, Knorosov also suggests that the text on the Santiago Staff is a list of names, a peculiar record of births (personal communication in Fedorova 1997). Attempts to find names in the Kohau Rongorongo texts, marked with a sign different from TB076 (Butinov and Knorosov, 1956; Butinov, 1959), cannot be considered successful.

In this manner the pattern of the name in the Kohau Rongorongo texts may be described by means of the formula: [A]-B-C-D, where $\mathbf{A}-$ sign "Man" (=TB200) - functions like the focus marker ko (Fedorova's article of the personal name) and is usually missing, $\mathbf{B}$ is a name that can be spelled with one or several signs, $\mathbf{C}$ is the father's name that can also be spelled with one or several signs and D - the sign "Phallus" (=TB076) - is the father name's marker ure. According to the formula, the boundary between the son's and the father's names is not marked.

The interpretation offered for the fragment on the Small Santiago tablet as well as that of the sign "Phallus" as a name marker looks convincing or at least interesting in the light of combinatory data and ethno-historic evidence. Nevertheless, some issues cast doubts on the validity of the hypothesis. Why is the $a$ possessive (marker of alienable possession) attested in all Polynesian languages in the name before the father's name (Englert, 1948: 333; Elbert and Pukui, 1985: 136-145) absent in the Kohau Rongorongo texts? What does the suffix -ure mean, if such a construction is unknown in the Polynesian languages? Why the suffix -ure is so infrequent in the other Kohau Rongorongo texts? Is it possible that personal names are almost absent there? Why does the sign "Man" appear exclusively in the genealogy on the Small Santiago Tablet and is absent before other names marked with the sign "Phallus", if it spells the focus marker ko, as has been suggested by Butinov and Knorosov?

\section{Distinctive Kohau Rongorongo texts}

In this paper, a text which shows distinctive distribution of a particular sign is termed distinctive text. In view of the fact that the objective of the paper is to examine names and their structure in the Kohau Rongorongo script, the attention will be concentrated on the Kohau Rongorongo tablets showing distinctive distribution of the sign TB076. There are three texts of this kind:

(1) Small Santiago Tablet, Verso,

(2) Santiago Staff, and

(3) Honolulu Tablet B.3629.

It should be noted that Recto and Verso of the Small Santiago Tablet present different texts, since the inscription on the side Recto is parallel to that of the Small London Tablet (Butinov and Knorosov, 1956). Moreover, TB076 is of frequent use on the Small Santiago Tablet, Verso $\mathrm{F}(\mathrm{TB} 076)=11.98 \%$, while the side Recto shows no distinctive distribution of the sign $\mathrm{F}(\mathrm{TB} 076)=0.56 \%$ (see Table 1$)$. The graphics of the Kohau Rongorongo script is poorly understood due to, among other things, a peculiar organization of the Barthel's catalogue (see for example, Vignes, 1990; Macri, 1996). Sometimes it is unclear in the catalogue if a sign is one or a combination of two or three signs. However, this fact doesn't have negative implications for statistical estimations of such kind.

The high frequency of use for the sign TB076 makes it possible to set apart the mentioned texts from the others. F(TB076) is $23.40 \%$ on the Santiago Staff, $22.76 \%$ on the Honolulu Tablet and $11.98 \%$ on the Small Santiago Tablet, Verso, whereas on the other texts it is equal to or less than $1 \%$ (see Table 1). To put it another way, the sign TB076 is very infrequent on the other tablets. At the same time, the structure of the two former texts is different from the last one as suggested by the distribution of TB076 (see

2. Following Sebastian Englert (1948: 333), Nikolai Butinov, Yuri Knorosov, Alexander Kondratov and Irina Fedorova term both the $k o$ focus marker and the $a$ possessive marker as "articles of the personal name". As I don't have a good descriptive grammar of Rapanui at my disposal, I will refer to Samuel Elbert and Mary Pukui's grammar of Hawai'ian (1985), a language closely related to Rapanui. 


\begin{tabular}{|c|c|c|c|}
\hline & $\mathrm{N}(\mathrm{TB} 076)$ & $\mathrm{N}_{\Sigma}$ & $\mathrm{F}(\mathrm{TB} 076)=\mathrm{N}(\mathrm{TB} 076): \mathrm{N}_{\Sigma} \times 100 \%$ \\
\hline Santiago Staff & 582 & 2487 & $23.40 \%$ \\
\hline Honolulu Tablet B. 3629 & 33 & 145 & $22.76 \%$ \\
\hline Small Santiago Tablet Verso & 43 & 359 & $11.98 \%$ \\
\hline Aruku-Kurenga Tablet & 8 & 1135 & $0.71 \%$ \\
\hline Atua-Mata-Riri Tablet & 0 & 357 & $0 \%$ \\
\hline Echancrée Tablet & 0 & 270 & $0 \%$ \\
\hline Great Santiago Tablet & 8 & 1580 & $0.51 \%$ \\
\hline Great St.-Petersburg Tablet & 6 & 1163 & $0.52 \%$ \\
\hline Great Washington Tablet & 3 & 600 & $0.50 \%$ \\
\hline Keiti Tablet & 5 & 822 & $0.61 \%$ \\
\hline Mamari Tablet & 0 & 1000 & $0 \%$ \\
\hline Small London Tablet & 0 & 163 & $0 \%$ \\
\hline Small Santiago Tablet Recto & 2 & 357 & $0.56 \%$ \\
\hline Small St.-Petersburg Tablet & 7 & 718 & $0.98 \%$ \\
\hline Small Vienna Tablet & 1 & 172 & $0.59 \%$ \\
\hline Tahua & 3 & 1825 & $0.16 \%$ \\
\hline
\end{tabular}

TABLE 1. - Distribution of the sign TB076 in the Kohau Rongorongo texts

Tables 2-4). The glyphic sequences marked with TB076 are separated by text fragments unmarked with TB076 on the Small Santiago Tablet, Verso, while the text on the Santiago Staff and Honolulu Tablet has no insertions of the unmarked with TB076 text. Average distance between neighbouring signs TB076 on the Santiago Staff and Honolulu Tablet and out of the unmarked text on the Small Santiago Tablet, Verso is more or less constant: it is equal to $3.04,3$, and 4.07 respectively. This fact suggests that the text marked with TB076 presents lists of names and $\mathrm{R}_{\mathrm{AV}}(\mathrm{TB} 076-076)$ reflects average length of the name in the Kohau Rongorongo texts expressed in number of signs. Basing on this observation, it is possible to conclude that the text on the Santiago Staff represents a single list consisting of 560 names or thereabouts.

As the distinctive distribution of the sign TB000 suggests, the text on the Santiago Staff is different in its structure from that on the Honolulu Tablet (see Table 4). The sign TB000 appears exclusively on the Santiago Staff, where it is attested 98 times and of frequent use $\mathrm{F}(\mathrm{TB} 000)=0.04$. TB000 is almost always found in the same position, coming in one-two signs before TB076 [ $\left.\mathrm{R}_{\mathrm{AV}}(\mathrm{TB} 000-076)=1.05\right]$. Sometimes the sign TB000 is called a special division mark or a punctuation symbol (Barthel, 1958, 1971, 1993; Fisher, 1995). It looks unlikely because the sign divides the text at irregular intervals, always appears in the same position associated with TB076 and is absent in the other texts. In all probability, the sign TB000 and signs following it are additional insertions of the text - some characteristics of mentioned persons or something like this - following or preceding the name $\left[\mathrm{R}_{\mathrm{AV}}(\mathrm{TB} 076-076)=4.69\right.$ for supposed names including TB000, and $\mathrm{R}_{\mathrm{AV}}(\mathrm{TB} 076-076)=3.12$ for names without TB000].

It is necessary to consider the beginnings and ends of the texts showing a distinctive distribution of TB076 in order to answer the following question: Is the sign TB076 initial or final one in its position in the name pattern? The Honolulu Tablet is too damaged to discern its beginning and end. The text on the Small Santiago Tablet, Verso begins with a sequence of names and ends with an unmarked fragment of text (Fig. 2). The initial sequence of names begins with an introductory sign and TB076, showing that TB076 rather functions as an initial sign there. The question of the opening and closing lines on the Santiago Staff is problematic, because lines cover all the surface of the staff. The lines on the Santiago Staff have been numerated by R.A. Philippi in an arbitrary way (Barthel, 1958: 24). Thomas Barthel maintained Philippi's arbitrary line order. The text consists of 13 equal lines of signs (Lines 1-11 and 13-14) and one additional brief line (Line 12) suggesting that the text begins with Line 13 and ends with Line 12 (Fig. 3A). Some compactness of the text in the end of Line 12 counts in favour of such interpretation, although it is unclear from Barthel's 


\section{Gv1}

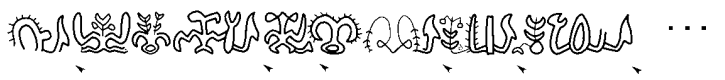

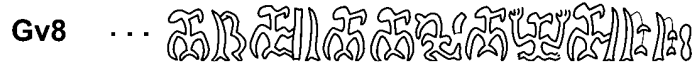

Figure 2. - Beginning (Line 1) and end (Line 8) of the inscription on the Small Santiago Tablet, Verso. The sign TB076 is marked off by arrows (after Paul Horley's drawings by his courtesy)

\section{A}
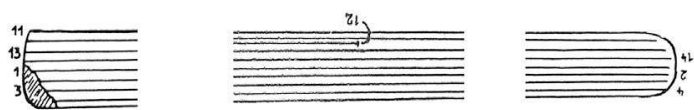

B

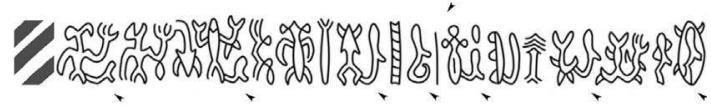

C

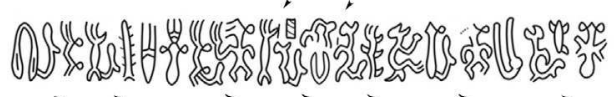

Figure 3. - Presumable beginning and end of the inscription on the Santiago Staff. The signs TB076 and TB000 are marked off by arrows. (A) Thomas Barthel's scheme of the inscription I. After drawings by Bodo Spranz (Barthel, 1958). (B) Probable beginning (Line 13) (after Paul Horley's drawings by his courtesy) (C) Probable end (Line 12) (after Paul Horley's drawings by his courtesy)

scheme why the line is shorter in the beginning, but not in the end. A good photo or examination in situ could probably make the case clearer. If the interpretation proposed here is correct, TB076 is rather an initial sign (Fig. 3B-C).

Final proof for the definition of TB076 as the initial sign in the name pattern comes from a close examination of the proposed genealogy from Small Santiago Tablet, Verso (Fig. 4). Names in the genealogical fragment evidently begin with the signs TB076-200. The widely accepted definition of TB076 as a final sign (Butinov and Knorosov, 1956; Barthel, 1958: 109-112; Fischer 1995) is probably based on the fact that it is found attached to the preceding signs. At the same time, it is well recognized that the conflation of signs is not used for dividing the text in words, sentences and the like in the Kohau Rongorongo script (Butinov and Knorosov, 1956; Barthel, 1958, 1971, 1993). Such a position of TB076 could be explained as a peculiar feature of the Kohau Rongorongo graphics to attach certain signs including TB076 to preceding ones. There are a lot of similar "abnormalities" in the graphics of many writing systems, for example, in the Mayan and Egyptian scripts. The explanation is supported by the form of TB076 itself as well as by the fact that some combinations of TB076 with certain signs on the Santiago Staff, for example, TB755-076-075 (not violating the distinctive distribution of TB076) almost always are conflations as well (Fig. 5).

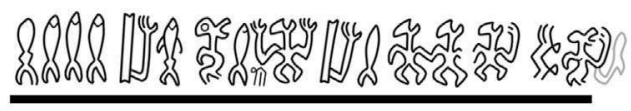

\section{Gv5}

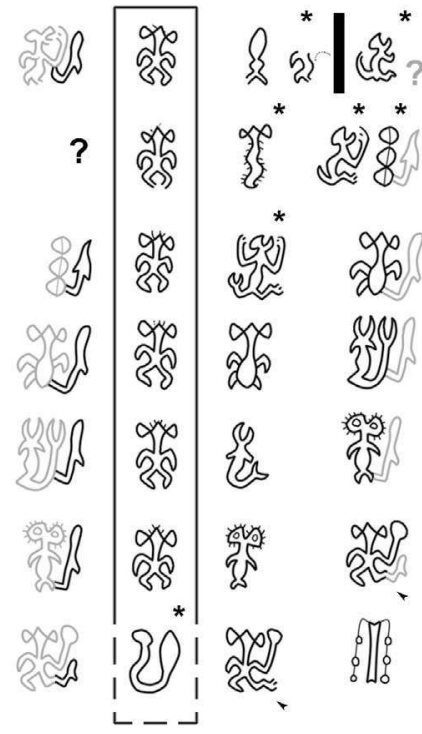

Gv7

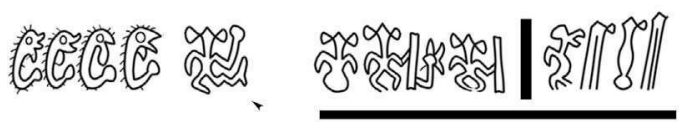

Notes on the figure. The sign TB076 in the first sequence is obliterated. In all probability, the same name - father's name in the first sequence and son's name in the second one represent two different ways of writing the same word: (1) syllabic spelling TB430-432 and (2) logographic spelling TB769, thus TB769 $=$ TB430+TB432 [TB430 is $\left(\mathbf{c}_{\mathbf{1}}\right) \mathbf{v}_{\mathbf{1}}, \mathrm{TB} 432$ is $\left(\mathbf{c}_{\mathbf{2}}\right) \mathbf{v}_{\mathbf{2}}$ and TB769 is $\left(\mathbf{C}_{\mathbf{1}}\right) \mathbf{V}_{\mathbf{1}}\left(\mathbf{C}_{\mathbf{2}}\right) \mathbf{V}_{\mathbf{2}}$ ]. Here $\mathrm{C}$ stands for a consonant, $\mathrm{V}$ for a vowel. From comparing the second and third sequences, it is possible to suggest that the sign group TB432-TB002 and the sign TB350? are used to write the same word as well, thus TB350? $=$ TB432+TB002 $=\left(\mathbf{C}_{\mathbf{2}}\right) \mathbf{V}_{\mathbf{2}}\left(\mathbf{C}_{\mathbf{3}}\right) \mathbf{V}_{\mathbf{3}}$ TTB432 $=\left(\mathbf{c}_{2}\right) \mathbf{v}_{2}$ (see above), TB002 $=\left(\mathbf{c}_{3}\right) \mathbf{v}_{3} ;$ cf. transliteration in Barthel 1958: 59]. The sign following TB076 in the seventh sequence represents a unique combination of signs TB062-TB073?, which is probably used to write the same title with two phonetic signs, thus TB200 = TB062+TB073? = $\left(\mathbf{C}_{4}\right) \mathbf{V}_{\mathbf{4}}\left(\mathbf{C}_{5}\right) \mathbf{V}_{5}\left[\mathrm{~TB} 062=\left(\mathbf{c}_{4}\right) \mathbf{v}_{4}\right.$, TB073 $\left.=\left(\mathbf{c}_{5}\right) \mathbf{v}_{5}\right]$. Less likely, it may be a rare allograph of TB200 with the identical phonetic value $\left[\right.$ TB200 $=\left(\mathbf{C}_{\mathbf{4}}\right) \mathbf{V}_{\mathbf{4}}\left(\mathbf{C}_{\mathbf{5}}\right) \mathbf{V}_{\mathbf{5}}, \mathrm{TB} 062+073=\left(\mathbf{C}_{\mathbf{4}}\right) \mathbf{V}_{\mathbf{4}}\left(\mathbf{C}_{\mathbf{5}}\right) \mathbf{V}_{\mathbf{5}}$. Even more unlikely, TB062-TB073 is used to spell another title. The signs in question are marked off by asterisks.

FIGURE 4. - Revision of the genealogy on the Small Santiago Tablet, Verso. The signs TB200 are marked off by the frame; the text unmarked with the sign TB076 is underlined (after Paul Horley's drawings by his courtesy) 
16

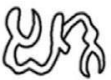

110

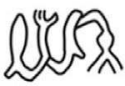

111

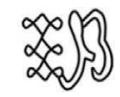

Santiago Staff, Line 6. TB755-076-075.

Santiago Staff, Line 10. TB073-006-076-075.

Santiago Staff, Line 11. TB002-076-078.

Figure 5. - Some examples of the conflation in the Kohau Rongorongo script (after Paul Horley's drawings by his courtesy)

\section{A}

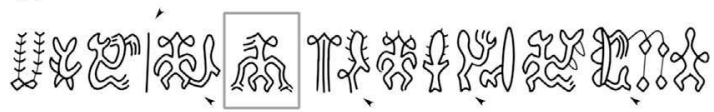

B

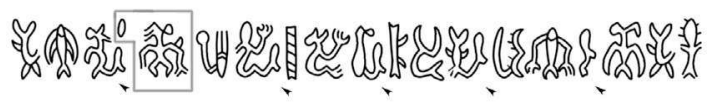

C

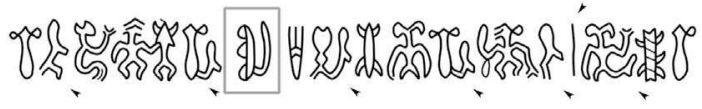

D

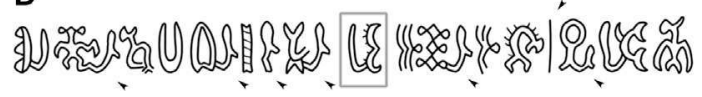

(a) TITLE $1 \mathrm{a}-$ TB530. Santiago Staff, Line 4.

(b) TITLE $1 \mathrm{~b}-$ TB021-530. Santiago Staff, Line 13.

(c) TITLE ${ }_{2}-$ TB020-010. Santiago Staff, Line 2.

(d) TITLE $_{3}$ - TB010-079. Santiago Staff, Line 14.

Proposed titles are marked off by the frame; the signs TB076 and TB000 are marked off by arrows.

Figure 6. - Titles in the Kohau Rongorongo texts (after Paul Horley's drawings by his courtesy)

\section{Distinctive signs of the Kohau Rongorongo texts}

In this paper, a sign which shows a distinctive distribution in texts is termed distinctive. A sign is distinctive if it appears in a certain position in respect to a certain sign. Taking into consideration the objective of this paper, the attention will concentrate on signs appearing in a certain position in respect to sign TB076. Another distinctive feature of signs is their capacity to form sequences of the kind $\mathrm{ABAB}, \mathrm{BABA}, \mathrm{AAAA}$ and AAA in combination with other signs. It has long been noted that such glyphic sequences are of frequent use in the Kohau Rongorongo texts (Butinov and Knorosov, 1956; Kondratov, 1969: 169-192). Moreover, it has also been suggested (Butinov and Knorosov, 1956; Kondratov, 1969: 169-192) that they correspond to the completely and partially reduplicated forms. Reduplication is a very productive grammatical process in Poly- nesian languages (see for example, Elbert and Pukui, 1985: 64-67). However, it should be highlighted that such a distinctive feature as the capacity to form sequences $\mathrm{ABAB}, \mathrm{BABA}$, AAAA and AAA strongly suggests that the sign has a phonetic (syllabic) value, just because word combinations such as, for example, "fish fish fish fish" mean nothing in any language (cf. TB700-700-700-700, Small Santiago Tablet, Verso, Line 5; Atua-Mata-Riri Tablet, Side $b$, Line 4). And vice versa the absence of this feature is indicative of a logographic value if the sign in question is presented with a sufficient number of examples in different contexts. I believe that this remarkable sign feature in rongorongo texts may be used to suggest and check reading values of signs.

Distinctive distribution of the signs TB076 and TB000 is described above. TB076 is a syllabic sign as suggested by sequences TB430-076-430-076, ТВ090-076-090-076, TB076-076-076, and perhaps TB076-276076-276 (Table 5). Besides, there are a number of examples of reduplication for the sign on the Santiago Staff, where its distribution predicts only one TB076 for a name. Contrariwise, TB000 doesn't form sequences ABAB, BABA, AAAA, AAA and it always occurs in the same position. Thus, the combinatorial data suggest a logographic value for TB000.

There are signs and combinations of signs which appear frequently in a certain position associated with TB076 on the Santiago Staff and the Honolulu Tablet. These are TB530 TB021-530, TB020-010, and TB010-079 (Fig. 6, Table 6). They appear after TB076, that is to say, in the initial position in the name. They seldom if ever occur in the medial and final positions in the name or in the text unmarked with ТВ076. Besides, there are no signs or sign sequences that show distinctive distribution in the medial and final positions. The fact that some combinations of signs appear in a certain position in the name strongly suggests that they represent titles. As this takes place, some names are complemented with titles, and some names are not. It is highly probable to find titles on the Kohau Rongorongo tablets in the light of what we know about Polynesian social organization (see for example, Kirch, 1984: 34-37). Various titles are attested in Rapanui folklore texts (Easter Island Manuscript E2: 1-6, in Barthel, 1974; text and translation are given after Fedorova, 1988: $15,46)$ :

3. Various variants of the sign and its conflations with other signs were numbered by Thomas Barthel as TB530-539. TB530 and TB532a represent different variants of the sign, the other numbers in the catalogue designate its conflations. 
komoehivaarikimaahul MoeHiva, arikimaahu 1, ko tukumauraariki maahu 2 kongeraniarikimaahu 3 ko poarikimaahu 4 kohenga arikimaahu 5

Erima maori o te ariki o otouta.

Tuku Maura, ariki maahu 2, Ngerani, arikimaahu 3, Po, arikimaahu 4 ,

Henga, arikimaahu 5.

(These) are five sages of the chief Oto Uta.

There is good evidence for interpretating the signs in the initial position after TB076 as titles. It is possible to carry out a statistical comparison between names mentioning supposed titles and names without them on the basis of the large list of names attested on the Santiago Staff. $\mathrm{R}_{\mathrm{AV}}(\mathrm{TB} 076-076)$ for names without titles and including them is equal to 3.00 and 3.46 respectively, and $\mathrm{R}_{\mathrm{AV}}(\mathrm{TB} 076-000)$ for names without titles and including them is 2.55 and 3.17. When $\mathrm{R}_{\mathrm{AV}}$ for names including titles is compared with $R_{A V}$ for names without titles, it is apparent that supposed titles represent additional insertions in names. It is reasonable to find such a pattern for titles. TB020-010 and TB010-079 designated here as TITLE ${ }_{2}$ and TITLE 3 are rarely attested, thus their identification as titles is presumable.

The sign TB530 is logographic (Table 5). TB530 depicts a "man in a headdress" (Fig. 6A) and Metoro's reading vie poko pono "femme coiffée/woman in a hat" seems to support such interpretation (Jaussen, 1893: 21; Heyerdahl and Ferdon, 1965: Fig. 83). Eugène Eyraud noted that, at the first look, all islanders were alike, because they had the same clothes (Englert, 1948: 228). Sebastian Englert adds that there were nevertheless a great variety of headdresses, although all were made from the same material found on the island (ibid.). Different kinds of headdresses are characterized by the length, the colour or the arrangement of feathers. Each, known by a special name, was worn on specific occasions and often had a symbolic meaning. Some of them, for example, hau tara, hau hiehie, hau veri, were associated with the chief (Métraux, 1940: 222-223). In the light of what has been mentioned above, it is possible to suggest that the sign for the title in question depicts a "Man in a headdress".

It is likely that TB530 and TB021-530 refer to the same title designated here as TITLE$_{1}$ (the variant TB530 is designated as TITLE 1 and TB021-530 - as TITLE ${ }_{1 b}$ ). Thus, the title in question is of the most frequent use on the Kohau Rongorongo tablets showing distinctive distribution of TB076 (Table 6), and yet it appears only 15 times on the other tablets. Although evidence supporting a syllabic value of the sign TB021 is rather weak, I suggest that
TB021 is a phonetic complement to TB530, since qualifiers always follow the nouns they modify in Rapanui (Englert, 1948: 337; Elbert and Pukui, 1985: 127): compare, for example, ariki and ariki henua, ariki maahu, ariki mau, ariki motongi, ariki nui, ariki paka, ariki tamahahine, ariki vaivai. Phonetic complements, which are not read but confirm the reading of a word sign nearby, are a distinctive feature of all known logosyllabic writing systems (see for example, Gelb, 1963: 250). In fact, a small number of ABAB, $\mathrm{BABA}, \mathrm{AAAA}$ and AAA sequences for TB021 may be ascribed to our lack of understanding of Kohau Rongorongo graphics, or to the fact that TB021 is an allograph (a variant of the sign), used mainly on the Santiago Staff. Taking into consideration a very high frequency of TITLE ${ }_{1}$, the tentative reading ('ARIKI) for TB530 could be proposed. If this reading is correct, TB021 should spell ('a): TB021-530 ('a)-('ARIKI) 'ariki "chief" (for the initial glottal stop see Blixen 1972).

The signs TB010, TB020 and TB079 which are used to spell possible titles and designated here as TITLE 2 [TB020-010] and TITLE $_{3}$ [TB010-079] are syllabic ones as their combinations with others signs suggest (Table 5). The sign TB200 is of frequent use, but it doesn't show a distinctive distribution in the texts marked with TB076. It is attested in ABAB, BABA, AAA and AA combinations with other signs (Table 5), suggesting its phonetic nature.

\section{Name pattern in the Kohau Rongorongo script reconsidered}

On the basis of the foregoing discussion and new added data, the name pattern in the Kohau Rongorongo tablets may be reexamined. We should first answer the question why the possessive $a$ is absent before the father's name in the genealogy on the Small Santiago Tablet. Such grammatical markers in similar contexts may be omitted; it is a well-known phenomenon in texts belonging to different cultures. Although there are no similar examples in surviving Rapanui folklore texts, we may find them, for instance, in the long genealogy of the Hawai'ian chant Kumulipo (Chant 11:717-721; after Beckwith, 1981: 205-206, 108):
Hanau o Loa'a ke kane
Nakelea ka wahine Nakelea the wife
Le [o] Kanu
Le [the husband of] Kanu [the wife]
Kalawe [o] Kamau Kalawe [the husband of] Kamau [the wife] 
Kulou [o] Halian Kulou [the husband of]
Haliau [the wife]

Some eight hundred pairs of names, of men and women, follow this fragment in the chant (ibid.: 109, 206-225). The $o$ possessive is omitted (as indicated with brackets above) in the entire list. It should be noted that the possessives $o$ and $a$ are nearly synonymous, in this case the difference is that $a$ (alienable possession) relates names of a son and a father, and $o$ (inalienable possession) relates names of a husband and a wife (Elbert and Pukui, 1985: 137). I suggest that the $a$ possessive in the names in the genealogy on the Small Santiago Tablet is absent for the very same reason. My attempts to find a possible candidate for (a) between names on the Santiago Staff have been unsuccessful. Nevertheless, I believe that it is due to our poor understanding of the Kohau Rongorongo graphics and that the $a$ possessive is to be found there.

Taking into account the possibility of omission of the $a$ possessive in the genealogy due to the clarity of the contexts and stylistic reasons, the meaning ure "patronymic marker" suggested for TB076 should be revised. As discussed above, TB076 is a syllabic sign attested in initial position, that is before names, in genealogies and name-lists. Compared with the available Rapanui genealogies and folklore texts (see some examples below), it becomes clear that TB076 functions like the ko focus marker:

The Estevan Atan Manuscript, Ko Hotu Matua (after Heyerdahl and Ferdon, 1965: Fig. 123):

ko hotu matua a taana harai Hotu Matu'a [son] of Taana Harai

ko tuu ma heke a hotu matua Tuu Ma Heke [son] of Hotu Matu'a

ko miru a tuu ma heke Miru [son] of Tuu Ma Heke

ko ataranga a miru

ko ihu a ataranga

Ataranga [son] of Miru Ihu [son] of Ataranga

The Juan Haoa Manuscript (after Heyerdahl and Ferdon, 1965: Fig. 150):

$\begin{array}{ll}\text { ko ira } & \text { Ira } \\ \underline{\text { ko }} \text { pukupuku } & \text { Pukupuku } \\ \text { nga tavake } & \text { Nga Tavake } \\ \underline{\text { ko } \text { kuukuu }} & \text { Kuukuu } \\ \underline{\text { ko } \text { uha tava }} & \text { Uha Tava } \\ \underline{\text { ko } \text { rapa renga }} & \text { Rapa Renga }\end{array}$

Comments: Ira, Kuukuu, Uha Tava, Rapa Renga are names of scouts sent in advance by Hotu Matu'a to Easter Island, and Nga Tavake together with Te Ohiro were the first settlers on Easter Island. Nga Tavake joined Ira and other scouts (Kondratov, 1965: 407).
E te tangata ko Atamu, ko Riro, o Atamu a Te Kena, ko Riro a Ngure, ko Atamu, ko Riro, te ariki, i oho o te mukomuko / The men Atamu, Riro, Atamu [son of] Te Kena, Riro [son of] Ngure, Atamu, Riro, the chiefs, were left without heirs

(The Estevan Atan Manuscript, Ko Hotu Matua, in Heyerdahl and Ferdon, 1965: Fig. 125, translation is given after Fedorova, 1978: 326, 328).

Thus, the comparison suggests TB076 to be the ko syllable. The proposed reading agrees with the following premises: the sign is syllabic, it precedes names in genealogies and lists of names. Besides, such a reading may explain the absence of TB076 in the unmarked text on the Small Santiago Tablet and in the Kohau Rongorongo texts different from those on the Small Santiago Tablet Verso, the Santiago Staff and the Honolulu Tablet. The ko focus marker is necessarily placed before names in lists and other quite limited contexts; one function of this grammatical particle is to mark appositions and consequently to introduce items of enumerations and lists (Englert, 1948: 333). The fact that TB076 is of low frequency in most tablets doesn't mean that names are absent there; that would be difficult to imagine in an early complex society. It only means that those names are unmarked with TB076 spelling the ko focus marker. Butinov and Knorosov's interpretation of TB076 as URE was based on the Metoro's readings ure, tupu, hua "phallus, offspring, fruit, fetus" (Fedorova, 1982: 56) as well as on the imagery of the sign depicting "phallus". It is well recognized that what a sign depicts shouldn't have any obvious bearing on its phonetic value, particularly if that sign is a syllable (see for example, Stuart, 1987). Nevertheless, it is possible to offer an explanation of why does the sign depicting "phallus" spells ko: the syllabic value (ko) may be derived via acrophony from the Rapanui kohio "miembro viril/penis"; see also kohio-hanga "cópula carnal/copulation" (Englert, 1948: 462) ${ }^{4}$.

The meaning of TB200 remains unclear. On one hand, TB200 appears in the position of a title in the genealogy on the Small Santiago Tablet (Fig. 4). On the other hand, it is of very frequent use and forms ABAB, BABA, AAAA and AAA sequences in combination with other signs that evidences for its phonetic nature. Furthermore, TB200 rarely occurs in the position of titles in the Kohau Rongorongo texts marked with TB076. There are two possibilities for resolving this contradiction. The first is that TB200 has

4. Acrophony is a process when a phonetic sign originates from the initial sounds of a logogram. Acrophony is of great concern in the origins of phonetic signs (see for example, Gelb, 1963: 251). 
two values: one syllabic value and one logographic, which refers to a rare title 5 . The second is to suggest that the signs TB076-200 in the genealogy correspond to ko te, and TB200 corresponds to the syllabic sign (te). Sometimes lists of names with ko te are attested in folklore texts (The War Between Tuu and Hotu-Iti II, in Métraux, 1940: 83):

He matau toroto to te ana The valiant warriors in the cave were

ko te Toki Heu,

ko te Toki Punipuni,

ko te Toki Rengorengo.

Toki Heu,

Toki Punipuni,

Toki Rengorengo.

My attempts to find ko te in genealogies and to propose an explanation for this grammatical construction (see for example, Englert, 1948: 332) were unsuccessful. That is the reason why I prefer not at present draw the ultimate conclusion about TB200.

The interpretation of the name pattern in the Kohau Rongorongo texts proposed in this paper may be summarized by means of the following formula: $[\mathbf{A}]-[\mathbf{B}]-\mathbf{C}-[\mathbf{D}]-\mathbf{E}$, where $\mathbf{A}(=\mathrm{TB} 076)$ is (ko) spelling the $k o$ focus marker, which appears before personal names in lists of names (and in genealogies in particular) and is absent in other contexts; $\mathbf{B}$ is a title that can be omitted; $\mathbf{C}$ is a name that can be spelled with one or several signs; $\mathbf{D}$ is the $a$ possessive and meaning "[son] of [father]", which is unattested in the genealogy on the Small Santiago Tablet, but possibly present in other names on the Kohau Rongorongo tablets; and $\mathbf{E}$ is father's name that can also be spelled with one or several signs.

To my knowledge, the only fact that argues against this interpretation is the name pattern. The interpretation suggests the title position to be strictly between the $k o$ focus marker and the personal name. Conversely, Sebastian Englert (1948: 333) writes that $k o$ is mainly used before personal names, especially after titles, for example: Te Ariki Ko Hotu Matu'a "the Chief Hotu Matu'a", Te Hakaora Ko Yêtú "the Savior Jesus". Indeed, the last construction is common in folklore texts along with the construction where a title with or without the $t e$ article follows the personal name with the ko subject marker, for example: Ko Ava Rei, tamahahine "Ava Rei, girl", Ko Tiki Hati A Tangaroa, ariki motongi "Tiki Hati A Tangaroa, paramount chief", Ko Rukunga, te ariki hopea "Rukunga, the last chief", Ko Atamu, te ariki tumu "Atamu, the legitimate chief". Nevertheless, I believe it is reasonable to assume that the title might be included in the personal name - such a phenomenon is attested in many early complex societies. In addition, the construction where a title precedes the name, either marked or unmarked with the $a$ article of personal names, is attested in folklore texts.

He hoki te tangata ko Hotu-iti, he noho te ariki Tu-ki-haka-he-vari i tōna kona. / The men of Hotu-iti came back. The king, Tu-ki-haka-he-vari remained in his country (A Tanga Roa, e te uha, after Métraux, 1937: 47).

He mate Oroi, he ariki Oroi o Hiva o Marae-Renga. I Thus died Oroi, a chief Oroi from Hiva from MaraeRenga (The Fight with Oroi, after Métraux, 1940: 67).

He noho he hakarata i te tangata te matua a Rute. I The father Roussel lived [on Easter Island and] taught islanders new faith

(The Estevan Atan Manuscript, Ko Hotu Matua, in Heyerdahl and Ferdon, 1965: Fig. 124; text and translation are given after Fedorova, 1978: 324, 326).

Ku tomo ro ai koe te ariki a Hotu Matua ku noho ro ai. / The chief Hotu Matua landed on the shore [and] settled [there]

(after Fedorova, 1965: 397).

\section{Content of the Kohau Rongorongo texts (sign TB076)}

Data obtained via structural analysis of undeciphered scripts have much potential for yielding information about the contents and purposes of texts (see for example, Urcid 2001). Thus, we may use the data at our disposal for understanding the contents and purposes of the Kohau Rongorongo texts. Furthermore, we should try to use the data for this objective, because otherwise we risk of offering readings and interpretations that make no sense in the contexts of Pre-European Easter Island's culture.

It has been noted before that it is natural and reasonable to expect the Kohau Rongorongo tablets to contain either genealogies of chiefs or lists of defeated enemies (Routledge 1919: 249; Knoche 1939; Butinov and Knorosov, 1956; Guy, 1998a). Both interpretations make sense in the light of what we know about pre-European Polynesia in general and Easter Island in particular. Social organization in Polynesia is frequently described as a conical clan, where the status and rank of a person depend on the genealogical distance from the lineage founder (see for example, Kirch, 1984: 31-34). Therefore genealogies should have been of paramount importance for the Rapanui at that time. Various titles, determining the status of the person and establishing relationships between individuals in the

5. The principle of polyphony - when individual signs have more than one canonical value - is well attested in world's writing systems (see for example, Gelb, 1963: 251). 
$[1]-\mathrm{A}-5-\mathrm{A}-\mathrm{B}-2-\mathrm{A}-3-\mathrm{A}-5-\mathrm{A}-4-\mathrm{A}-4-\mathrm{A}-5-\mathrm{A}-[3]-\mathrm{A}-4-\mathrm{A}-7-\mathrm{A}-3-\mathrm{A}-9-\mathrm{A}-9-$
$\mathrm{B}-\mathrm{A}-3-\mathrm{A}-5-\mathrm{A}-5-\mathrm{A}-5-\mathrm{A}-4-\mathrm{A}-4-\mathrm{A}-4-\mathrm{A}-7-\mathrm{A}-5-\mathrm{A}-5-\mathrm{A}-5-\mathrm{A}-4-\mathrm{A}-21-\mathrm{A}-5-5$
$\mathrm{~A}=13-\mathrm{B}-\mathrm{B}-31-\mathrm{AB}-3-[\mathrm{A}] \mathrm{B}-3-\mathrm{A}-2-\mathrm{AB}-2-\mathrm{A}-2-\mathrm{A}-2-\mathrm{B}(?)-7-\mathrm{A}-1-\mathrm{B}-2-\mathrm{B}-6-$
$\mathrm{A}-1-\mathrm{B}-6-\mathrm{A}-7-\mathrm{A}-4-\mathrm{A}=31-\mathrm{B}-6-\mathrm{A}-6-\mathrm{A}-9-\mathrm{A}-10$

Numbers denote the distance between two neighboring signs TB076 or TB200 expressed in number of signs between; the genealogy is marked by the double line; the text unmarked with TB076 is underlined.

TABLE 2. - Distribution of the signs TB076(A) and TB200(B) on the Small Santiago Tablet, Verso

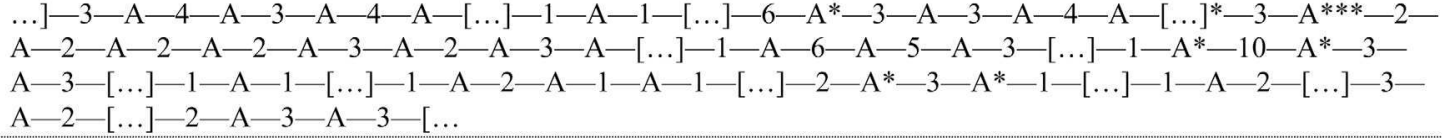

Numbers denote the distance between two neighboring signs TB076 expressed in number of signs between; [...] indicates damaged signs; ${ }^{*}$ is TITLE $_{1}$, and ${ }^{* *}$ is TITLE $_{3}$.

TABLE 3. - Distribution of the signs TB076(A) on the Honolulu Tablet B. 3629

society, play a large role in every early complex society. On the other hand, lists of defeated and sacrificed enemies narrating about exploits of chiefs and proving the presence of the sacred power mana of an 'ariki and his glorious ancestors, could legitimize his authority. As this takes place, Kohau Rongorongo texts were an important media of sociopolitical integration on Easter Island. The results presented above show that the genealogy on the Small Santiago Tablet, Verso, is not a genealogy in the strict sense, although true genealogies were probably written on the tablets as well. It is a genealogical fragment written in reverse order and inserted into a name list which evidently refers to the most prominent person mentioned there. It is used to supply reference to the person with genealogical information mentioning his ancestors in at least 6 generations. Besides this, three discussed Kohau Rongorongo texts differ in their genres: (1) the Honolulu Tablet presents a list of names marked in part with titles, (2) by contrast, the text on the Santiago Staff contains insertions marked with TB000, and (3) in the text on the Small Santiago Tablet six sequences of names from 3 to 13 names (Table 2) - are separated by fragments of the text unmarked with ТВ076.

Although the data are too deficient to make ultimate conclusions, it is possible to compare these three texts in their genres with the following kinds of Kohau Rongorongo boards, from which only the descriptive names were known from the natives: kohau o te tangata mate "tablets of the dead" used to record the names of deceased men; kohau o te ranga "tablets of fugitives" used to record the names of fugitives and prisoners; kohau ika "tablets of victims" used to record the names of slaughtered or sacrificed; and, less probably, kohau ta'u "tablets of years" which were registers of births made by tangata tapu ta’u (Métraux, 1940: 394-395; Englert, 1948: 321, 462; Barthel, 1971: 1168). The interpretation of kohau ta' $u$ as "registers of births" obtained from some islanders differs from the more common one "annals recounted events of the past". According to Sebastian Englert (1948: 462), this information should be considered doubtful. It is interesting that the tablets with the names of sacrificed men, called kohau ika, were suspended on every funerary cairn $a h u$ (see Knoche 1939: 32).

\section{Conclusion}

Structural analysis from a conservative viewpoint makes it possible to suggest a more refined and consistent description of the names in the Kohau Rongorongo texts in comparison with the original proposal offered by Nikolai Butinov and Yuri Knorosov and eventually substantiates their interpretation of the fragment on the Small Santiago Tablet as a genealogy. It shows promise for looking at the Kohau Rongorongo script as a logo-syllabic writing system that employs syllabic spellings and phonetic complements and does not omit grammatical markers excluding those cases when the language itself permits to omit them. The proposed here content interpretation of the text on Santiago Staff is in agreement with ethno-historic data at our disposal and with what we know about the social organization of pre-European Easter Island. Representing one more example of artificial bilinguals found, the tentatively identified titles may be used for detection and verification of phonetic values for the signs attested as their constituents. 




Numbers denote the distance between two neighboring signs TB076 or TB000 expressed in number of signs between; [...] indicates damaged signs; $*$ is TITLE $_{1}, * *$ is TITLE $_{2}$, and $* * *$ is TITLE $_{3}$.

TABLE 4. - Distribution of the signs TB076(A) and TB000(B) on the Santiago Staff 


\begin{tabular}{|c|c|c|}
\hline & $\begin{array}{c}\text { Combinations } \\
\text { with other signs }\end{array}$ & Inscription \\
\hline 000 & - & \\
\hline \multirow[t]{5}{*}{076} & $076-076$ & $\mathrm{I} 2, \mathrm{I} 3, \mathrm{I} 5$, etc. \\
\hline & $076-076-076$ & \\
\hline & $430-076-430-076$ & Br10, Hr9, Qr9, etc. \\
\hline & 090-076-090-076 & I4 \\
\hline & $076-276-076-276 ?$ & Pr8 \\
\hline \multirow[t]{5}{*}{010} & $001-010-001-010$ & Ab2, Pr8, Hr9 \\
\hline & $067-010-067-010$ & Pv5, Ev3, Hv2 \\
\hline & $020-010-020-010$ & Pv5, Pv8, Qv7, etc. \\
\hline & $079-010-079-010$ & Ev1, Ev7 \\
\hline & $010-067-010-067$ & Hv11 \\
\hline \multirow[t]{4}{*}{020} & $020-020$ & Ra7, Ev6 \\
\hline & $020-700-020-700$ & $\operatorname{Pr} 10, \mathrm{Qv} 1, \mathrm{Hr} 10$ \\
\hline & $020-010-020-010$ & Pv5, Pv8, Qv7, etc. \\
\hline & $020-003-020-003$ & Hv12 \\
\hline \multirow[t]{2}{*}{021} & $207-021-207-021$ & $\mathrm{Ra} 2$ \\
\hline & $300-021-300-021 ?$ & Ab3 \\
\hline \multirow[t]{3}{*}{079} & $079-079$ & $\mathrm{Nb} 2, \mathrm{Sa} 1$ \\
\hline & $079-275-079-275$ & Bv11 \\
\hline & $079-010-079-010$ & Ev1, Ev7 \\
\hline \multirow[t]{7}{*}{200} & $200-200$ & Aa5, Bv1, Pr6, etc. \\
\hline & $200-200-200$ & Pr4, Ra1, Qr4, etc. \\
\hline & $200-047-200-047$ & $\mathrm{Ra} 2$ \\
\hline & $605-200-605-200$ & $\mathrm{Rb} 5$ \\
\hline & $200-001-200-001$ & $\mathrm{Hr} 2, \mathrm{Hv} 6$ \\
\hline & $200-560-200-560$ & Hv4 \\
\hline & $200-053-200-053$ & $\mathrm{Hv} 5$ \\
\hline 530 & - & \\
\hline
\end{tabular}

Abbreviated references on the inscriptions follow the system elaborated by Thomas Barthel (1958): A - Tahua Tablet, B - Aruku-Kurenga Tablet, E - Keiti Tablet, H - Great Santiago Tablet, I - Santiago Staff, N-Small Vienna Tablet, PGreat St.-Petersburg Tablet, Q - Small St.-Petersburg Tablet, R - Atua-Mata-Riri Tablet, S - Great Washington Tablet; $\mathrm{r}$ and $\mathrm{v}$ - sides Recto and Verso, $\mathrm{a}$ and $\mathrm{a}-$ Sides a and $\mathrm{b}$; digit indicates the number of line.

TABLE 5. - Distinctive signs and their combinations ABAB, BABA, AAAA, AAA, AA in the Kohau Rongorongo texts

\section{Acknowledgements}

I would like to thank Vladimir Belikov (Department of South Pacific Studies, Institute of Oriental Studies, Russian Academy of Science, Moscow), whose knowledge of Polynesian languages and cultures is second to none, for a very fruitful discussion and his regular help. I would also like to thank Dmitri Beliaev (Knorosov Center for Mesoamerican Studies, Russian State University for the Humanities, Moscow) for his comments on the epigraphic part of the work. A special acknowledgment must go to the author of the website http:// www.rongorongo.org. I also would like to thank Evgenia Korovina, Martyn Harris, Paul Horley, Rafal M. Wieczorek and Tomi Melka who encouraged me to publish this paper and helped me discussing issues concerned here. I am very much obliged to Paul Horley for his kind suggestion to use his unpublished drawings for the redone figures.

\section{Addenda}

The paper was originally written for and presented at the $2^{\text {nd }}$ International Conference "Hierarchy and Power in the History of Civilizations" held in St.-Petersburg, Russia, in 2002 (Davletshin, 2002). Unfortunately, I had no opportunity to publish it at that time, but it was distributed between scholars and cited in the literature (see for example: Horley, 2011). So, I have decided to publish it as it was written with minor stylistic corrections; figures were redone on the basis of new drawings. It reflects the original reasoning and shows the ways I have arrived at my conclusions. My knowledge of Rapanui language and of Kohau Rongorongo have considerably improved in these years, but my opinion on the main ideas suggested in the paper, cautious as they are, remains unchanged. But I would now like to add a few comments which will probably be the most interesting part of the article. Remarkably, many changes are related to the documentation of the Kohau Rongorongo texts which has been greatly improved. Several works published in recent times concern the topic of this paper (Guy, 2004; Bettocchi, 2009; Horley, 2011; Melka, 2009; Nikolay, 2001).

1. As regards the beginning of the text on the Santiago Staff, I believe that Paul Horley (2011) has offered the best solution for the identification of the reading order, opening and closing lines. It would be impossible to make it without many photographs, rubbings and casts Horley worked with. Although my conclusions were grounded, the data at my disposal were not sufficient.

2. Today I believe that sign TB076 represents not the "phallus", but "a kind of plant", i.e., kohe "cierta planta que crece en la costa/a kind of plant growing on the shore" (Englert, 1948), proto-Polynesian *kofe " 1 . bamboo spp. 2. bamboo knife" (Biggs and Clark, n.d.).

3. Examining photos (see Ramírez and Huber, 2000), I can tell that the sign TB200 in the genealogy on the Small Santiago Tablet is different from its common version because it always 


\begin{tabular}{|l|c|c|c|c|}
\hline & N after B076 & N after no B076 & N after B076 & N after no B076 \\
\cline { 2 - 5 } & \multicolumn{2}{|c|}{ Santiago Staff } & \multicolumn{2}{c|}{ Honolulu Tablet B. 3629 } \\
\hline TITLE $_{1 \mathrm{a}}$ & 46 & 7 & 5 & 1 \\
\hline TITLE $_{1 \mathrm{~b}}$ & 10 & 0 & 0 & 0 \\
\hline$\sum$ & 61 & 8 & 0 & 0 \\
\hline TITLE $_{2}$ & 13 & 4 & & 0 \\
\hline \hline$\sum$ & 13 & 4 & 1 & \\
\hline TITLE $_{3}$ & 10 & 0 & & \\
\hline \hline$\sum$ & 11 & 0 & & \\
\hline
\end{tabular}

TABLE 6. - Supposed titles and frequencies of their use in various positions in respect of TB076 in the Kohau Rongorongo texts. The totals $(\Sigma)$ are given for both texts (Santiago Staff and Honolulu Tablet B. 3629)

has four additional lines at the head (hair?, a kind of headdress?). I suggest that it is a different sign, not slotted in Thomas Barthel's notation. It behaves as a logogram and is attested in the position of titles on the Small Santiago Tablet. Thus, it probably spells a word denoting a title.

4. In 2002 neither Steven Fischer's drawings of the text I (Fischer, 1997), nor photos of the inscription were available to me. Nowadays, I think that the sign TB021 of the Santiago Staff is iconically different from the TB021 found in other texts. It is probably a logograph used to spell one more title in the text on the Santiago Staff.

5. Thanks to the new drawings available (Fischer 1997; see also Melka 2009: 38, footnote 37), it is clear that the Honolulu Tablet B.3629 does possess at least two examples of the sign TB000: in line Ta4 and in line Ta7. Thus, the text on the Santiago Staff and the text on the Honolulu Tablet most likely share the same genre.

6. The text on the Santiago Staff is more structured than is presented here and permits a more refined analysis with important implications for its interpretation.

7. It is possible to arrive at the reading of TB076 as ko spelling "focus marker" and at the interpretation of the text on the Santiago Staff as a name-list independently from the Small Santiago's genealogy. The Santiago Staff represents a list of some 560 items of more or less equal length, 3 signs on average, each of them marked with sign TB076. The ko focus marker in Rapanui language is used for introducing items in lists and enumerations of any kind. Lists unmarked with the $k o$ focus marker are agrammatical, so $k o$ should be there and TB076 is the only possible solution. Thus, 560 individual items of a list that are almost never repeated in the text should represent personal names, even if they would be personal names of Easter Island stone statues. The last suggestion seems to be unlikely from an anthropological point of view. This observation unnoticed in the literature is important, because it makes the interpretation stronger ( $c f$. Nikolay, 2001: 9).

8. Currently, I am a little bit sceptical about the analysis concerning Figure 4's notes. Strangely, TB076 seems to be missing after the first name and two possible substitutions are attested in the first part of the supposed genealogy. These two facts make the substitution problematic. No other examples of substitutions with these signs are found in the text. The focus marker ko can introduce not only names in a genealogy, but also items of any list. Thus, we can assume that the whole passage represents a list of three names marked by a title (names 1-3) and the last one of them, possibly, referring to a very important person (name 3), is followed by a short genealogy indicating four generations of his ancestors (names 4-7). However, in this case it is difficult to explain why at least six members of the list are specified by the same title. Significantly, this title is not attested in other contexts in the present text and in the Kohau Rongorongo texts in general. I believe that until an alternative logical explanation for this distortion in the structure of the genealogy will be found, the hypothesis of the suggested substitutions should be maintained. From my point of view, this kind of analysis is promising and important for the Kohau Rongorongo studies.

\section{Abbreviations and conventions}

N(A): Number of the signs A in a text.

$\mathrm{N}_{\Sigma}$ : Total number of all the signs in a text.

F(A): Frequency of use for the sign A expressed as the percentage of the number of the signs A to the total number of all the signs in a text $\left[\mathrm{F}(\mathrm{A})=\mathrm{N}(\mathrm{A}): \mathrm{N}_{\Sigma} \times 100 \%\right]$.

$R_{A V}(A-B)$ : Average distance between the neighbouring signs $\mathrm{A}$ and $\mathrm{B}$ expressed in the number of signs between them. 
This paper employs the system of graphic transcription elaborated by Thomas Barthel (1958), to whose catalogue three-digit numbers associated with the capital letters TB refer. TB000 stands for the "Vertical Line" sign, which is absent in the catalogue and appears exclusively on the Santiago Staff. Working with the graphics I try to be independent from Thomas Barthel's catalogue, so I also refer to the signs discussed with their descriptive nicknames, for example, "Turtle". This nickname doesn't mean that the sign is read "turtle" or depicts it, but only that it looks like one.

The system of glyphic transliteration is traditional (see for example: Fox and Justeson, 1984). Logographic signs are printed in capitals ('ARIKI), while phonetic signs are printed in small letters (ko); both are given in bold case. Parentheses highlight the presumable nature of the offered phonetic readings.

\section{BIBLIOGRAPHY}

BARTHEL Thomas, 1958. Grundlagen zur Entzifferung der Osterinselschrift, Abhandlungen aus dem Gebiet der Auslandskunde 64, Reihe B: Völkerkunde, Kulturgeschichte und Sprachen Band 36, Hamburg, Cram, de Gruyter.

_, 1959. Häuptlingsgenealogien von der Osterinsel, Tribus 8, S. 67-82.

-, 1971. Pre-Contact writing in Oceania, in Thomas A. Sebeok (ed.), Current trends in linguistics 8: Linguistics in Oceania, Den Haag-Paris, Mouton, pp. 1165-1186.

—, 1974. Das achte Land: die Entdeckung und Besiedlung der Osterinsel, München, Klaus Renner.

_, 1993. Perspectives and directions of the Classical Rapanui script, in Steven Roger Fischer (ed.), Easter Island studies: contributions to the history of Rapanui in memory of William T. Mulloy, Oxford, Oxbow Monographs in Archaeology 32, pp. 174176.

BECKWITH Martha Warren, 1981 ( $2^{\text {nd }}$ edition). The Kumulipo, a Hawaiian creation chant, Honolulu, University of Hawai'i Press.

BetTocchi Lorena, 2009. Le bâton du maître des signes, Kadath 105, pp. 56-64.

Biggs Bruce and Ross Clark, n.d. Polynesian Lexicon Project Online (http://pollex.org.nz/).

BLIXEN Olaf, 1972. La oclusión glótica del pascuense, Moana 1 (5), pp. 1-20.

Butınov Nikolai А. [БУТИНОВ Н.А.], 1959. Иероглифические тексты острова Пасхи (Рапа-Нуи), Вестник мировой культуры 3, с. 69-80, Лениград [in Russian: Hieroglyphic texts of Easter Island].
Butinov Nikolai A. and Yuri V. Knorosov [БУТИНОВ Н.А., КНОРОЗОВ Ю.В.], 1956. Предварительное сообщение о письме острова Пасхи, Советская этнография 4, с. 77-91 [Also appeared as Butinov Nikolai A. and Yuri V. Knorosov].

-, 1957. Preliminary report on the study of the written language of Easter Island, Journal of the Polynesian Society 66 (1), pp. 5-17.

Davletshin Albert, 2002. From Kohau Rongorongo tablets to Rapanui social organization: From Rapanui social organization to Kohau Rongorongo script, in Dmitri Beliaev and Sergey A. Frantsuzov (eds.), Second International Conference Hierarchy and Power in the History of Civilizations (St.Petersburg, July 4-7, 2002), Abstracts, Moscow, p. 249.

Elbert Samuel H. and Mary Kawena Pukui, 1985 ( $2^{\text {nd }}$ edition). Hawaiian grammar, Honolulu, University of Hawaii Press.

ENGLERT Sebastian, 1948. La tierra de Hotu Matu'a: historia, etnología y lengua de la Isla de Pascua, Santiago de Chile, Padre Las Casas.

Fedorova Irina К. [ФЁДОРОВА И.К.], 1965. Versions of myths and legends in manuscripts from Easter Island, in Thor Heyerdahl and Edwin N. Ferdon (eds), Reports of the Norwegian archaeological expedition to Easter Island and the East Pacific, vol 2: Miscellaneous papers, Stockholm, Forum, Monographs of the School of American Research and the Kon-Tiki Museum 24, pp. 395-401.

-, 1978. Мифы, предания и легенды острова Пасхи, Москва [in Russian: Myths, lore and legends of Easter Island].

—, 1982. Исследование рапануйских текстов, в Ю.В. Кнорозов ред.) Задытые системы письма: остров Пасхи, великое ляо, Индия (материалы к дещифровке), Москва с. 23-98 [in Russian: Study of Rapa Nui texts].

—, 1988. Мифы и легенды острова Пасхи, Ленинград [in Russian: Myths and legends of Easter Island].

—, 1997. О характере текста на жезле с острова Пасхи, в Е.В. Ревуненкова, Н.А. Бутинов (ред.), этнография, история, культура стран южных морей: Маклаевские чтения 1995-1997 г2., C.-Петербург, с. 64-69 [in Russian: Nature of the text on the staff from Easter Island].

FISCHER Steven Roger, 1993. A provisional inventory of the inscribed artifacts in the three Rapanui scripts, in Steven Roger Fischer (ed.), Easter Island studies: contributions to the history of Rapanui in memory of William T. Mulloy, Oxford, Oxbow Monographs in Archaeology 32, pp. 177-181.

- 1995. Preliminary evidence for cosmogonic texts in Rapanui's rongorongo inscriptions, Journal of the Polynesian Society 104, pp. 303-321.

-, 1997. Rongorongo: the Easter Island script, History, traditions, texts, Oxford, Clarendon Press.

Fox James A. and John S. Justeson, 1984. Conventions for the transliteration of Mayan hieroglyphs, 
in John S. Justeson and Lyle R. Campbell (eds), Phoneticism in Mayan hieroglyphic writing, Albany, State University of New York at Albany, Institute for Mesoamerican Studies Monograph 9, pp. 363366.

GelB Ignace J., 1963 ( $2^{\text {nd }}$ edition). A study of writing: a discussion of the general principles governing the use and evolution of writing, Chicago-London, University of Chicago Press.

GuY Jacques, 1998a. Probable nature and contents of the Santiago Staff, Rapa Nui Journal 12 (4), p. 109.

—, 1998b. Easter Island - Does the Santiago Staff bear a cosmogonic text? Anthropos 93 (4-6), pp. 552-555.

-, 2004. Where does the Santiago staff begin? Rapa Nui Journal 18 (1), pp. 39-41.

HARrison J. Park, 1874. The hieroglyphics of Easter Island, Journal of the Royal Anthropological Institute of Great Britain and Ireland 3, pp. 370-382.

Horley Paul, 2011. Palaeographic analysis of the Santiago staff, Rapa Nui Journal 25 (1), pp. 31-43.

ImBelLoni José, 1951. Las “tabletas parlantes" de Pascua, monumentos de un sistema gráfico indooceánico, Runa 4, pp. 89-177.

JAUSSEN Florentin Étienne, 1893. L'île de Pâques : historique, écriture et répertoire des signes des tablettes ou bois d'hibiscus intelligents, Bulletin de la Société de Géographie 2, pp. 240-270.

KIRCH Patrick Vinton, 1984. The evolution of the Polynesian chiefdoms, Cambridge-New York, Cambridge University Press.

KNOCHE Walter, 1939. Einige Beziehungen eines Märchens der Osterinsulaner zur Fischverehrung und zu Fischmenschen in Ozeanien, Mittheilungen der Anthropologischen Gesellschaft in Wien 69, S. 24-33.

KonDRATOV Alexander M. [КОНДРАТОВ A.M.], 1965. The hieroglyphic signs and different lists in the manuscripts from Easter Island, in Thor Heyerdahl and Edwin N. Ferdon (eds), Reports of the Norwegian archaeological expedition to Easter Island and the East Pacific, vol 2: Miscellaneous papers, Stockholm, Forum, Monographs of the School of American Research and the Kon-Tiki Museum 24, pp. 403-411.

—, 1969. Статистические методы дешифровки некоторых письмён Востока и Средиземноморья, Дис. канд. ист. наук, Институт Народов Востока AHCCCP [Statistical methods of decipherment of some writing systems of the East and the Mediterranean, Unpublished Ph.D. thesis, Institute of Oriental Studies, USSR Academy of Science].
—, 1976. Письменность острова Пасхи, в Н.М. Дьяконов (ред.), Тайны древних письмён: проблемы дешифровки, Москва с. 531-538, 559 [in Russian: Writing of Easter Island].

KudRJAvtsev Boris G. [Кудрявцев Б.Г.], 1949. Письменность острова Пасхи, Сборник музея антропологгии и Этнографии 11, с. 175-221 [in Russian: Writing of Easter Island].

MACRI Martha J., 1996. Rongorongo of Easter Island, in Peter T. Daniels and William Bright (eds), The world's writing systems, New York-Oxford: Oxford University Press, pp. 183-188.

Melka Tomi S., 2009. Some considerations about the Kohau Rongorongo script in the light of a statistical analysis of the Santiago Staff, Cryptologia 33 (1), pp. 24-73.

MÉTraux Alfred, 1937. The kings of Easter Island, Journal of the Polynesian Society 46 (2), pp. 4162

_, 1940. Ethnology of Easter Island, Honolulu, Bernice P. Bishop Museum Press, Bernice P. Bishop Museum Bulletin 160.

Nicolay Scott, 2001. Structure and content of the Easter Island inscriptions, unpublished manuscript.

Piotrowski A., 1925. Deux tablettes avec les marques gravées de l'île de Pâques de la collection de N. N. Mikloukho-Maklay, Revue d'Ethnographie et des Traditions Populaires 6 (23-24), pp. 425-31.

Ramírez José Miguel and Carlos Huber, 2000. Easter Island: Rapa Nui, a land of rocky dreams, Santiago: Alvimpress Impresores.

RoutLedge Katherine, 1919. The mystery of Easter Island. London: Hazell, Watson and Viney.

STUART David, 1987. Ten phonetic syllables, Washington D.C., Research Reports on Ancient Maya Writing 14.

URCID SERRANo Javier, 2001. Zapotec hieroglyphic writing, Washington D.C., Studies in Pre-Columbian Art and Archaeology 34.

Vignes Jacques. 1990. Is a new approach to the decipherment of Rongorongo script necessary? in Heide-Margaret Esen-Baur (ed.), State and perspectives of scientific research in Easter Island culture, Frankfurt a.M., Courier Forschungsinstitut Senckenberg 125, S. 115-119. 